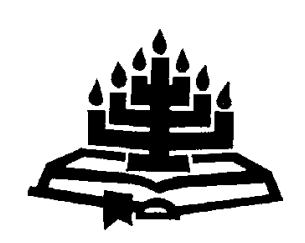

\title{
Die kontekstualisering van die Nuwe Testament binne 'n postmodernistiese paradigma: die skep van betekenis of die toepas van betekenis?
}

\author{
S.P. van der Walt \& G.J.C. Jordaan
}

Skool vir Bybelwetenskappe en Bybeltale

Potchefstroomkampus

Noordwes-Universiteit

POTCHEFSTROOM

E-pos: spvdw@absamail.co.za

sbbgjcj@puk.ac.za

\begin{abstract}
Contextualisation of the New Testament within a postmodern paradigm: Creation of meaning or application of meaning?

Owing to a largely postmodernist paradigm new emphasis on preaching the Bible in a modern-day context has emerged over the last few decades. Scholars operating within the sphere of this new paradigm are committed to the deconstructionist views of text and meaning. Rejecting the notion of "the meaning" of a text, their idea of contextualisation is to create a new meaning for a text for each new context. Consequently, a number of "contextual theologies" have arisen in which the context of the reader has become a determinant for the meaning of the text. In this article, however, the contextualisation of the Biblical message is argued from a Reformed viewpoint. Based on the conviction that the Bible, as Word of God, is not time-bound but time-addressed, it is argued that although the Biblical text originated within the context of the first readers, it is not restricted to the context of the first readers. The Biblical text also addresses the context of the readers of all times. Hence contextualisation does not imply creating a new meaning for every new context, but rather finding the link between original context and contemporary context. The hermeneutical process identifying and applying this link is known as hermeneusis.
\end{abstract}


Opsomming

Die kontekstualisering van die Nuwe Testament binne 'n postmodernistiese paradigma: die skep van betekenis of die toepas van betekenis?

In hierdie artikel word die kontekstualisering van die Bybel beredeneer vanuit ' $n$ gereformeerde hoek. Kontekstualisering het in die huidige postmoderne denkklimaat weer onder die soeklig gekom - grootliks vanweë die besondere klem wat hierdie paradigma plaas op die toepassing van die Bybelboodskap op die hedendaagse konteks. Navorsers wat binne die raamwerk van die postmodernistiese paradigma werksaam is, word grootliks gelei deur die dekonstruksie-benadering van teks en betekenis waarvolgens die teks op sigself betekenisloos is. Die kontekstualisering binne 'n postmodernistiese denkklimaat behels die skep van betekenis vir elke nuwe konteks. Gevolglik het 'n aantal kontekstuele teologieë of belangeteologieë die lig gesien waar die konteks van die leser bepalend is vir die betekenis wat vanuit die teks voortvloei. Die gereformeerde benadering tot kontekstualisering aanvaar dat die Bybel, as Woord van God, nie tydgebonde is nie, maar tydgerig. Hierdie beginsel behels dat die teks wel aan 'n eerste groep lesers gerig was, maar nie beperk is tot die konteks van daardie lesers nie; dit is ook gerig op die konteks van lesers van alle tye. Kontekstualisering lê dus nie daarin dat 'n nuwe betekenis uit die teks geskep moet word nie, maar wel om die skakel tussen die konteks van die eerste lesers en die konteks van die moderne lesers te vind. Die hermeneutiese proses waarbinne hierdie skakel gevind en toegepas word, staan bekend as hermeneuse.

\section{Inleiding}

Die verskyning van die postmodernisme op die wetenskaplike horison het daartoe gelei dat teoloë gedurende die afgelope dekade druk begin besin het oor die invloed wat hierdie nuwe denkwyse op die teologiese wetenskap mag hê (De Villiers, 1991; Rossouw, 1993; Veldsman, 1994; Deist, 1994a; Jordaan, 1994; Vorster, 1996; 1999b; Van Deventer, 1999; Groothuis, 2000). Hierdie besinning gaan egter gebuk onder die frustrasie dat die verskynsel wat as "postmodernisme" bekend staan, moeilik definieerbaar is. Dit is immers wesenlik van die postmodernisme dat dit nie konformeer aan enige definisie of akkurate beskrywing nie (Adam, 1995:1; De Villiers, 1991:147; Tracy, 1994:107; Vergeer, 1999:13; Ward, 1997: 585). Die postmodernisme is nie 'n beweging of 'n metode nie; dit kan hoogstens 'n denkklimaat genoem word en getipeer word aan 
die hand van bepaalde algemene tendense wat in die wetenskap gestalte vind. Wat die teologie betref, blyk dit dat die postmodernistiese denkklimaat hom veral op twee terreine laat geld, naamlik die verklaring van die Bybel (vgl. Herholdt, 1998a:215), en die toepassing van die Skrifboodskap (Duvenage, 1999:27; Jordaan, 1999: 16; Vergeer, 1999:13; Vorster, 1999a:11).

Sowel Skrifverklaring as -toepassing het te doen met die betekenis van die Bybelteks vir vandag (Draper, 1991:235). Daarom vereis hierdie artikel 'n kort voorafbesinning oor wat met "teks" (van die Bybel) en "betekenis" bedoel word (vgl. Snyman, 1992b:358; Vorster, 1996:11). Hierdie besinning verg egter 'n verdere voorafbesinning, naamlik 'n oorsig oor kenteoretiese vertrekpunte waarop die hantering van teks en betekenis berus (vgl. Snyman, 1992a:247249). Die betekenis van die teks vir vandag staan ook direk in verband met die begrip kontekstualisering. Gevolglik word teks en betekenis in hierdie artikel in verband gebring met kontekstualisering. Daarna word aangetoon watter invloed die denkraamwerk van die postmodernisme tot dusver op die hantering van kontekstualisering gehad het. Uiteindelik word hierdie invloed vanuit die gereformeerde beskouings oor Skrif, betekenis en kontekstualisering beoordeel.

\section{Verskuiwings in kenteoretiese vertrekpunte}

Ten einde die verskillende sienings oor "teks" en "betekenis" - veral binne die postmodernistiese denkklimaat - en die invloed daarvan op Skrifverklaring en Skriftoepassing te verstaan, is dit nodig om eers duidelikheid te kry oor paradigmaverskuiwings en kenteoretiese vertrekpunte wat die grondslag daarvan vorm. Ruimte laat egter slegs 'n oorsigtelike beskrywing van hierdie paradigmaverskuiwings en vertrekpunte toe.

\subsection{Paradigma en paradigmaverskuiwing}

'n Paradigma is 'n werklikheidsbeskouing wat navorsers se uitgangspunte en benadering tot die veld van hulle ondersoek bepaal (vgl. Kuhn, 1970:viii). Die beskouing kan bewustelik of onbewustelik bestaan en gaan die reëls en teorie van wetenskaplike ondersoek vooraf (vgl. Vorster, 1996:11). Volgens Vorster (1994:316; 1996:11) het hierdie beskouing van Kuhn via die hermeneutiek in die teologie inslag gevind as 'n beskrywing van die uitgangspunte wat die teorie van Skrifverstaan voorafgaan. 
'n Paradigmaverskuiwing vind plaas wanneer die bestaande model verruil word vir 'n ander (nuwe) model, omdat die ouer model nie meer probleme in die veld van ondersoek kan oplos nie (Van Aarde, 1988:51-52; Van Deventer, 1996:444). Enkele navorsers het al probeer om die paradigmaveranderings wat in die teologiese wetenskap plaasgevind het, te beskryf (bv. Lategan, 1984:2-4; Spangenberg, 1994:145-161; Van Deventer, 1999:404-410). Lategan (1984:2-4) se beskrywing hou verband met die wesenskenmerke van 'n teks wat tydens teksinterpretasie op die voorgrond kom (vgl. Van Deventer, 1999:408; Wright, 2000:35-54). Spangenberg (1994:145-161) sê weer dat die paradigmaverskuiwings verband hou met die gebruik van bepaalde verklaringsmetodes (vgl. Van Deventer, 1999:408). Van Deventer (1999:407-410) bied egter die mees aanvaarbare verklaring vir paradigmaverskuiwings in die teologie, naamlik dat dit telkens in die geskiedenis plaasgevind het as gevolg van 'n veranderde kenteoretiese vertrekpunt (vgl. ook Vorster, 1998:209). Van Deventer (1999:408) identifiseer drie paradigmaverskuiwings wat in die loop van die geskiedenis plaasgevind het, naamlik 'n premodernistisiese paradigma, 'n modernistiese para digma en 'n postmodernistiese paradigma.

\subsection{Vanaf premodernisme na modernisme}

Van Deventer (1999:408) beskryf die kenteoretiese vertrekpunt van die premodernistiese paradigma as 'n waarheidsbeskouing wat slegs dit "wat deur die tradisie as (geopenbaarde) waarheid aanvaar is" as waar aanvaar (vgl. ook Hendriks, 1996:492). Vorster (1999a: 10) tipeer die premodernistiese paradigma soos volg:

Die mens- en kultuurbeskouing [was] pessimisties en alles [is] gedoen onder leiding van die geloof in die beheer van metafisiese kragte. Die ontwikkeling van wetenskap en tegnologie het agterweë gebly. In die Christelike gemeenskappe het die kerk 'n leidinggewende rol gespeel en is die geloof nooit bevraagteken nie.

Hierdie tyd is gekenmerk deur die onaanvegbare gesagsposisie van die pous en die klerus (Vorster, 1999a:10). Die gevolg hiervan was dat die verstaan en verklaring van die Bybel van die kerk afhanklik gemaak is (Greijdanus, 1946:180). Binne hierdie kerksentriese samelewing van die premoderne paradigma (Vorster, 1999a:10) word teologiebeoefening as skolasties getipeer, veral as gevolg van die invloed van Thomas van Aquino (Gaybba, 1998:41).

Met die Renaissance het 'n paradigmaverskuiwing begin intree. Dit het plaasgevind omdat die dominansie van die metafisiese stelsel- 
matig en toenemend bevraagteken is (Vorster, 1999a:10). Gevolglik het die Middeleeuse binding van kerk en kultuur al losser geraak en verder uitmekaar beweeg. Ook die wetenskap is deur die Renaissance vernuwe (Berkhof \& De Jong, 1967:231-232) en hoë verwagtings van die wetenskap is geskep. Hierdie verwagtings van die wetenskap het daartoe gelei dat die menslike rede in die filosofie al meer as bron van gesag beskou is (Vorster, 1999a:10). Op hierdie wyse het die denkstroom van die rasionalisme ontwikkel onder invloed van veral Descartes, Spinoza en Leibniz. Die mens het daarvan oortuig geraak dat die menslike verstand, wat alreeds soveel vermag het, tot nog veel meer in staat kan wees. Nie soseer die mens nie, maar die rede van die mens, het die maatstaf geword waaraan alles gemeet is (Berkhof \& De Jong, 1967:231-232). Met die rede as grondmotief vir die menslike lewe is die tyd van die Verligting ingelui. Rasionalisme en humanisme het die godsdiens verdring (vgl. Dalferth, 2000:9). Tereg beskryf Van Deventer (1999: 408) die kenteoretiese vertrekpunt van die modernistiese paradigma soos volg: dat slegs dít waar is wat deur wetenskaplike metodes as waar bewys is.

Die wetenskaplike denkklimaat van die modernisme het verder gelei tot die sogenaamde subjek-objek-onderskeiding (Hendriks, 1996: 495). Klem het op die objek geval en wetenskap is gesien as 'n "rasionele aktiwiteit wat deur 'n sekere logika of metode gelei word terwyl dit na 'n heel spesifieke ideaal van objektiwiteit gestreef het" (Botha, 1988:4). Hierdie beskrywing is eie aan die opkoms van die positiwisme en die ontwikkeling van logiese positiwisme (vgl. Schulze, 1981:79-104).

Implikasies vir die teologie en hermeneutiek in hierdie tyd was volop. Jordaan (1994:2) verwys na die negentiende-eeuse realisme en naturalisme wat daarvan uitgegaan het dat die objektiewe werklikheid kenbaar is en dat taal 'n medium is waardeur die werklikheid geken kan word. Vir die hermeneutiek het dit beteken dat die Bybel beskou is as 'n beskrywing van die werklikheid. Gevolglik is op 'n rasionalistiese en positiwistiese wyse omgegaan met die vraag na betekenis en waarheid in die Skrif. Hieroor sê Vorster (1996:64) dat die Bybel in die tyd van die modernisme op rasionele wyse gedissekteer is todat net die etiese eise van die Skrif oorgebly het. Die modernisme van die laat-negentiende eeu en vroeg-twintigste eeu het gelei tot Skrifkritiek en ongekende sekularisasie (Vorster, 1999a:11). Tot en met die eerste helfte van die twintigste eeu is geloof en godsdiens onder druk geplaas. Die mens het ontoeganklik geword vir religieuse ervaring en toeganklik vir dit wat rasioneel bewys en hanteer kan word (Vorster, 1996:9). 
Samevattend: In die premodernistiese paradigma is betekenis afhanklik gestel van kerklike uitleg en toepassing van die Skrifboodskap. In die modernistiese paradigma moes die Bybel spreek tot ' $n$ moderne, mondige mens, en alles wat nie betrek is op die mens in sy tyd nie, is nie as geldig beskou nie (Vorster, 1977:14). Skrifwaarhede was afhanklik van die objektiewe bepaalbaarheid daarvan.

\subsection{Vanaf modernisme na postmodernisme}

Die modernistiese beskouing van die rede as outonome subjek wat in staat sou wees om Skrifwaarhede objektief te bepaal, het in die eerste helfte van die twintigste eeu toenemend onder druk gekom. Die belangrikste rolspelers was Dilthey, Bultmann, Gadamer, Derrida en Kuhn (vgl. Van Deventer, 1998:81). Dilthey kom in verset teen die idee dat die geskiedenis enigsins empiries vasgestel kan word. Verstaan is dus altyd relatief tot die verstaner se tyd en omstandighede en daarom is interpretasie nooit afgehandel nie (Rossouw, 1981:34-41). Later worstel ook Rudolf Bultmann met die vraag of eksegese sonder voorveronderstellings moontlik is (Porter \& Clarke, 1997:14; Van lersel, 1982:116). Hy kom dan tot die konklusie dat elke verklaarder 'n teks benader met 'n sekere wêreldbeskouing en dat die onderdrukking van hierdie wêreldbeskouing onmoontlik is (Silva, 1994:230).

In skerp kontras met Descartes, en in 'n mindere mate met Dilthey, was een van die mees prominente figure in die Duitse teologie sekerlik Hans-Georg Gadamer, wie se naam meermale geassosieer word met 'n relativistiese benadering tot interpretasie (vgl. Silva, 1994:232). Gadamer spreek hom uit teen enige poging tot 'n objektiewe verstaan van die teks en meen dat dit juis belangrik is dat die eie konteks van die interpreteerder deel vorm van die hermeneutiese proses (Van Deventer, 1998:81). Saam met Bultmann is Gadamer dus ook oortuig dat vooroordele nie vermy kan word nie. Volgens Gadamer is gebeure en tekste uit die verlede nie vas nie - dit verander namate dit voortdurend "herverstaan" word (Silva, 1994:233). Hiermee is die basiese boustene van die kenteoretiese vertrekpunt daargestel waarop die postmodernistiese paradigma uiteindelik sou berus, naamlik dat absolute waarheid nie bereikbaar is nie, aangesien die waarheid relatief is (Van Deventer, 1999:408).

'n Sterk impuls vir die opkoms van die postmodernisme was die ontstaan van die dekonstruksie wat in die sestigerjare deur Derrida as leesstrategie ontwerp is (vgl. Blank, 1986). Volgens die de- 
konstruksie is dit wat die outeur bedoel het en dit wat die taal van die teks sê, twee verskillende dinge. Die dekonstruksie probeer nie eens om vas te stel wat die outeur se bedoeling was nie, want dit is nie haalbaar nie en buitendien irrelevant. Wat egter in die herlees van die teks gebeur, is dat die taal 'n nuwe betekenis tot stand bring. So word daar by elke herlees van die teks 'n nuwe betekenis geskep. Taal is dus betekenisskeppend.

Die finale breuk met die modernistiese paradigma het gekom met die verskyning van Thomas Kuhn se boek The Structure of Scientific Revolutions in 1967 (vgl. Deist, 1994a:167 en Silva, 1994:233), wat met enkele bywerkings weer onder dieselfde titel in 1975 (Kuhn, 1975) uitgegee is. Met verwysing na hierdie bydrae van Kuhn skryf Vorster (1996:11):

Kuhn toon dat wetenskaplike navorsing in die nuwe paradigma bepaal word deur 'n lewens- en wêreldbeskouing wat sekere beginsels as voorveronderstelling in die navorsingsproses daarstel. Die navorser, ook die teoloog, benader sy veld van ondersoek nie neutraal, onbelas of objektief nie.

Hieruit is dit dus duidelik dat Kuhn se nuwe paradigma die weg vir die postmodernisme in die wetenskap, ook die teologiese wetenskap, gebaan het.

\section{Teks en betekenis}

In bostaande oorsig van die kenteoretiese vertrekpunte is verskeie kere terloops verwys na veranderde beskouings oor teks en betekenis. Omdat die begrippe "teks" en "betekenis" 'n sentrale plek in die hele gesprek oor kontekstualisering inneem, moet eers kortliks oor hierdie twee begrippe besin word. Oor "teks" en "betekenis" is daar al soveel geskryf dat dit onmoontlik is om binne die omvang van een artikel volledig daaroor te skryf. Vir die doel van hierdie artikel word dus slegs oorsigtelik oor hierdie twee begrippe gehandel en besin oor die verhouding tussen die twee.

Die tradisionele gereformeerde Skrifbeskouing berus op 'n siening dat die teks, in casu die teks van die Bybel, 'n geskrewe objek is wat as 'n gegewe eenheid in die geskiedenis tot stand gekom het. As sodanig sou hierdie teksbeskouing aan die premoderne wetenskapsparadigma toegeskryf kon word en word dit inderdaad ook binne die postmodernistiese denkklimaat as "naïef" bestempel (vgl. Draper, 1991:235). 
Volgens die gereformeerde Skrifbeskouing het die teks van die Bybel sy (vaste, bepaalbare) betekenis ontvang binne die historiese konteks waarin dit geskryf is (Stanton, 1977:66-67). Om by die betekenis van die teks uit te kom, word die teks dan volgens historiese metodes (grammatika, styl, sosiohistoriese konteks) ontleed. Op hierdie punt vertoon die gereformeerde Skrifbeskouing 'n ooreenkoms met die modernistiese paradigma, wat aanvaar dat daar 'n objektiewe werklikheid bestaan wat deur die teks (van die Bybel) vir die mens kenbaar is. Tog verskil die gereformeerde beskouing van teks en betekenis ingrypend van die modernisme, veral vanweë die rasionalistiese grondslag van die modernisme.

Volgens die gereformeerde siening is teks en betekenis onlosmaaklik aan mekaar verbonde. Die feit dat die teks sy betekenis in die geskiedenis ontvang het, beteken egter nie dat die Skrif (ten opsigte van teks en betekenis) in die geskiedenis vasgevang is nie. Die Skrif is immers nie tydgebonde nie maar tydgerig (Coetzee, 1997:15). Barth (1968:1-2) stel dit soos volg:

Paul spoke as a son of his own time for his own contemporaries. But there is a much more important truth than this: Paul speaks as a prophet and apostle of the Kingdom of God to all men of all times.

In die eerste helfte van die twintigste eeu het Bultmann egter teks en betekenis van mekaar geskei. Volgens hom word betekenis nie maar net deur die teks bepaal nie, maar is betekenis afhanklik van die leser se verwysingsraamwerk (Vorverständnis) en sy konteks (vgl. Stanton, 1977:67). Die leser "verstaan" nie die teks uit wat daar geskryf staan nie, maar in 'n proses van "rekonstruksie" kom die leser tot die eintlike betekenis van die teks (Draper, 1991:236). Daarmee het Bultmann 'n deur oopgemaak vir die latere konsep van "kontekstualisering" (Draper, 1991:242).

In die sestiger- en sewentigerjare is die skeiding tussen teks en betekenis nog verder gevoer. Binne die denkklimaat van die opkomende postmodernistiese wetenskapsparadigma het resepsieteoretici, soos Jauss en Iser, gestel dat daar nie so iets soos 'n selfstandige en objektiewe teks bestaan nie. Hulle stel dat 'n teks net in terme van sy ontvangs (resepsie) beskryf kan word. Dit wat geskrywe staan, is niks meer nie as 'n lesersaanbod wat die (hedendaagse) leser vanuit sy eie realiteit (konteks) met 'n bepaalde betekenis invul (vgl. Lategan, 1984:10-12). Sodoende is die "teks" nie 'n selfstandige artefak nie, maar iets wat in interaksie tussen die 
lesersaanbod en die leser ontstaan. Hiermee is reeds die grondslag van postmodernistiese kontekstualisering gelê.

Die postmodernisme se beskouing van teks en betekenis is egter ten diepste gegrond op die leesstrategieë van die dekonstruksie. Die dekonstruksie se siening van die betekenisskeppende aard van taal word in die postmodernistiese denke 'n treetjie verder geneem: ook die teks is betekenisskeppend. ' $n$ Teks het nie betekenis nie, maar skep betekenis deurdat betekenis telkens in die leesproses daaraan toegeken word. So word die teks ten opsigte van betekenis 'n oop aangeleentheid (Hunter, 1987:130). Dit staan die leser vry om 'n teks te lees en te interpreteer soos hy wil (Hartin, 1991:189). Hierdie interpretasiewillekeur is van deurslaggewende belang vir die manier waarop kontekstualisering binne die postmodernisme plaasvind.

\section{Kontekstualisering}

Om die begrip "kontekstualisering" te definieer, is nie 'n eenvoudige saak nie. Die Conceptual Dictionary gee 'n baie algemene definisie, naamlik "to place or view a phenomenon in its context" (Withers, 1994:47). In die teologiese wetenskap gaan dit spesifiek daaroor dat die teks of die boodskap binne 'n konteks geplaas word. Oor die wat en die hoe van die konteks is daar egter uiteenlopende aksente. Daarom word die woord "kontekstualisering" in die literatuur op verskillende maniere gebruik.

Vergeer (1993:27) beskou kontekstualisering as 'n strategie wat deur die Bybelskrywers gevolg is om die boodskap wat hulle wou oordra, by hulle lesers tuis te bring. Wendland (1999) sluit by hierdie siening aan en beskryf Paulus se strategie van kontekstualisering soos volg: "He seemingly shaped and adapted his theological and ethical content to suit the circumstances of its reception" (Wendland, 1999:203).

In die Missiologie word die begrip "kontekstualisering" heeltemal anders aangewend. Dit word naamlik gebruik as 'n term om die verinheemsing van die evangelie in die tradisionele kultuur van die sendingobjekte te benoem (Vogel, 1989:7). Veral die Afrikanisering van die evangelie staan in die kalklig (vgl. Wendland, 1999; Ukpong, 2001:148-158; England, 2004:96). Wendland (1999:220) verkies om eerder na die Afrikanisering van die evangelie te verwys as rekontekstualisering.

Vir Draper (1991:239) is kontekstualisering die proses om betekenis toe te eien ("appropriation of meaning") vir die moderne leser. 
Draper vind aansluiting by Bultmann se benadering van re-konstruksie as deel van die ontmitologiseringsproses van die teks. In navolging van die woord "re-konstruksie" gebruik Draper ook die term "re-kontekstualisering" (Draper, 1991:241-242). Binne hierdie raamwerk is kontekstualisering dan 'n gebeurtenis wat deel vorm van elke individuele leser se eksistensiële verstaan van die teks (vgl. Draper, 1991:241).

Van Wyk (1995:259) het weer 'n heeltemal ander beskouing van kontekstualisering. Hy wys tereg daarop dat die gereformeerde teologie nie konteksloos - dus wêreldvreemd - kan of wil wees nie. Hoewel daar as gevolg van die historiese belading van die woord "kontekstualisering" gewoonlik gehuiwer word om daaraan 'n staanplek binne die gereformeerde teologie te gee, bestaan daar tog so iets soos 'n legitieme kontekstualiteit binne die gereformeerde teologie. Die Woord van God moet immers hier en nou in ons lewens inkom en gestalte kry in ons verhoudings en situasies, maar natuurlik sonder dat daar iets van die Bybelse boodskap prysgegee word (Van Wyk, 1995:259). In gereformeerde terme kan die woord "kontekstualisering" dan uiting gee aan die feit dat die tydgerigtheid van die Woord van God ook inhou dat dit op die konteks van vandag gerig is. Daarom kan die Woord van God, as Woord van God, met vrug gebruik word om die hedendaagse konteks te betrek (vgl. Floor, 1979:16-17).

\section{Kontekstualisering in 'n postmodernistiese denk- klimaat: om betekenis te skep}

Hierbo is reeds aangetoon dat Derrida se siening dat taal betekenis skep, binne die postmodernistiese paradigma so aangepas is dat ook die teks as betekenisskeppend beskou word. Wanneer Jauss en Iser se beskouing dat 'n teks ontstaan op grond van die interaksie wat tussen die leser en die geskrewe lesersaanbod ontstaan, hierby gevoeg word, is die belangrikste bestanddele bymekaar vir kontekstualisering binne die denkklimaat van die postmodernisme. Hiervolgens is kontekstualisering 'n proses waarin die interaksie tussen die teks (lesersaanbod) en die leser betekenis tot stand bring. Hierdie betekenis word dan bepaal deur die konteks van die leser. Omdat elke leser vanuit sy eie konteks lees en sy konteks nie noodwendig met dié van die volgende leser ooreenstem nie, lei dit daartoe dat die betekenis wat geskep word, telkens 'n nuwe betekenis sal wees, wat verskil van enige betekenis wat by 'n vorige leeshandeling tot stand kon gekom het. 
As voorbeeld van hierdie wyse van kontekstualisering neem Draper (1991) die Kairos-dokument van 1986. Draper (1991:243) skryf hieroor soos volg:

The Kairos Document calls on the Church in South Africa to take the option for the poor, to choose the community of the oppressed over against the community of the powerful and the rich. My hermeneutic also deliberately chooses to read the text within the community of the oppressed ...

Hy verduidelik sy keuse om die Bybel vanuit die gesigspunt van die armes te lees soos volg (Draper, 1991-243):

Strictly speaking, the word of God is not to be found in the letter of scripture. Nor is it in the spirit of the hearing or reading community. It is precisely between these two, in their mutual, dynamic relationship, in a back-and-forth that is never perfectly objectifiable.

Die gevolg van hierdie wyse van kontekstualisering is dat die Woord in die werklikheid opgaan in plaas daarvan dat die Woord die werklikheid binnegaan (Van Wyk, 1995:259; vgl. ook D'Assonville, 1976:91). Die gevaar hiervan is dat normatiewe status aan die konteks van die leser toegeken word en dat sy konteks voorrang bo die Skrif kan geniet (vgl. Lategan, 1984:6).

Samevattend kom dit daarop neer dat betekenis nie aan die teks van die Bybel verbind word nie, maar dat betekenis in die leesproses deur die leser aan die teks toegeken word. In hierdie betekenisskepping is die konteks van die leser bepalend. Dit is waarby kontekstualisering binne die denkklimaat van die postmodernisme uitkom.

\section{Konsekwensies van betekenisskeppende kontekstualisering}

\section{1 Skrifbeskouing}

Die standpunt van die dekonstruksie ten opsigte van die betekenisskeppende aard van taal het verreikende konsekwensies vir die wyse waarop die Skrif gesien word. In hierdie opsig word weer verwys na Spangenberg (1994) se tipering van paradigmaveranderinge binne die Bybelwetenskappe (2.1 hierbo). Spangenberg beskryf drie paradigmas in die Protestantse tradisie, naamlik die hervormingsparadigma, die histories-kritiese paradigma en laastens die literatuurwetenskaplike paradigma. Wat Skrifbeskouing 
betref, word die Bybel binne die hervormingsparadigma gesien as "die Woord van God", binne die histories-kritiese paradigma as "Gods Woord in mensetaal", en binne die literatuurwetenskaplike paradigma as "Woorde oor God" (Spangenberg, 1994:161). Hoewel Van Deventer (1999:408) hierdie paradigmas eerder as premodernisties, modernisties en postmodernisties tipeer, stem hy oor die tipering van die drie onderskeie Skrifbeskouings skynbaar met Spangenberg saam.

Uit Spangenberg en Van Deventer se uiteensettings kan afgelei word dat die postmodernistiese paradigma 'n Skrifbeskouing huisves wat die Bybel sien as "woorde oor God". Hierdie afleiding korreleer met die opmerking van Herholdt (1998b:468) dat, ten opsigte van die hermeneutiek binne 'n postmodernistiese denkklimaat, "the Bible does not serve as a fixed record of God's communication, but as an example of the way in which people experienced and understood God in the past" (eie kursivering SPvdW \& GJCJ).

In aansluiting hierby skryf Herholdt (1998b:467) dat die postmoderne mens (dus ook navorser/wetenskaplike/teoloog) die Bybel nie benader asof dit 'n bron van waarheid is wat ontdek moet word nie, maar dat waarheid gevind word in die verhouding tussen die leser met die teks. Waarheid is daarom nie 'n voorafbepaalde entiteit nie, maar dinamies en word medebepaal deur die behoeftes, voorveronderstellings, religieuse agtergrond en kulturele erfenis wat deur die individu na die Bybel gebring word. Alhoewel Herholdt skerm teen moontlike kritiek asof hierdie standpunt 'n gees van relativisme adem, bly hy in gebreke om die teendeel bevredigend aan te dui. Van Deventer (1999:408) dui dus tereg aan dat waarheid binne 'n postmodernistiese paradigma soos volg beskryf kan word: wat waar is, is relatief. 'n Objektiewe waarheid en absolute beginsels het dus plek gemaak vir relatiewe waarheid as een van die gevolge van die huidige postmodernisme (Vorster, 1999b:107).

'n Nadere kwalifisering van die relativisme is te vind by Kuitert se relasionele waarheidsbegrip, wat baie ooreenkomste vertoon met die gedagtegang van Herholdt soos vroeër bespreek. Neven (1993:5) beskryf Kuitert se Skrifbeskouing hiervolgens as volg:

... wat Israël over God dacht en wat de evangelisten en apostelen - als toevoeging daaraan - over Jesus dachten. Niets meer, niets minder. Hiermee is de Bijbel eigenlijk alleen nog 'oorkonde' van de menselijke ervaring van God. De Bijbel 
blijft dan wel belangrijk, maar hij is uiteindelik niet meer dan een wegwijzer.

Kuitert se Skrifbeskouing word saamgevat in sy bekende uitspraak: "Alles wat wij over boven zeggen, komt van beneden" (vgl. De Jong, 1993:10).

\subsection{Belangeteologieë}

In die tyd van die opkoms en ontwikkeling van 'n postmodernistiese denkklimaat het die histories-kritiese benadering in die hermeneutiek toenemende kritiek begin ontvang. Die groeiende ontevredenheid met die eksegetiese resultate van die histories-kritiese metode impliseer nie soseer 'n naïewe verwerping van al wat onder "histories-krities" ressorteer nie, maar eerder die behoefte aan eksegetiese resultate wat die mens binne sy omstandighede en konteks raak (Draper, 1991: 238). Die ontstaan van die kontekstuele teologie kan gesien word as die manifestasie van hierdie behoefte (Lategan, 1984:6).

Die kontekstuele teologie het op sy duidelikste na vore getree in die verskillende belangeteologieë (vgl. Lategan, 1984:6) of genitiefteologieë soos wat dit ook dikwels genoem word (vgl. Jordaan, 1994:6). Voorbeelde van resente belangeteologieë is die materialistiese eksegese (vgl. Lategan, 1984), die feministiese teologie (vgl. Loades, 1997; Chopp, 1997), swart teologie (vgl. Maimela, 1998), Afrikateologie (vgl. Mbiti, 1998), bevrydingsteologie (vgl. De Wit, 1995) en wit teologie (vgl. Kruger, 1991). Die wekroep van al hierdie belangeteologieë is dat die eksegese van die Bybel meer praktiese aangeleenthede moet aanraak. Dus moet die leser 'n groter rol in die eksegeseproses speel sodat die werklike sosiale en kulturele behoeftes aangespreek kan word. In die praktyk kom dit daarop neer dat die verband tussen die teks en die werklikheid bloot vanuit die sosiale konteks van die leser gelê word. Gevolglik het elkeen van hierdie belangeteologieë ideologies gelade geraak (Lategan, 1984: 6).

Ukpong (2001:154) meen dat "issues like race, gender, class, sexual orientation, social, economic and political contexts have come to be acknowledged as shaping the way the Bible is read" in Afrika (eie kursivering - SPvdW \& GJCJ). Hy sê verder: "Attention has shifted from the history of the text to the text itself and the interpreters of the text and their contexts" (Ukpong, 2001:163). Die postmodernistiese klanke slaan sterk deur in Ukpong (2001:151) se pleidooi dat die konteks na die teks toe gebring moet word. So blyk 
dit dat die konteks die bril word waardeur daar na die Bybel gekyk word.

Van Wyk (1995:260) se kritiek hierop is dat "die evangelie nie na die konteks toe gebring word nie, maar uit die konteks afgelei word". Waar die konteks die bepaler van betekenis word, noem Van Wyk (1995:259) dit kontekstualistiese teologie. Dit moet onderskei word van kontekstuele teologie waar die werklikheid verstaan word deur die bril van die Bybel. ' $n$ Kontekstualistiese teologie hoef nie summier te ressorteer onder feministiese, swart, Afrika- of wit teologie nie. Waar die konteks egter só 'n sentrale plek sou inneem dat die Woord daarin opgaan, in plaas daarvan dat die Woord daar ingaan (= die konteks binnedring), ontstaan die gevaar dat betekenis geskep word vir die behoeftes van die konteks. In so 'n geval word eksegese dus nie gerig op die konteks van die hedendaagse mens nie, maar word dit juis daardeur bepaal.

\section{Kontekstualisering in die gereformeerde hermeneutiek: om betekenis toe te pas}

In 3 is reeds daarna verwys dat die Skrif in die gereformeerde hermeneutiek nie as tydgebonde beskou word nie, maar as tydgerig. Met tydgerig word primêr bedoel dat die Bybel in sy teboekstelling gerig was op die situasie van die eerste lesers. Terselfdertyd het God die Bybel gegee om die mense van alle tye in hulle konteks en omstandighede te raak. Die eksegetiese proses waardeur die Skrifboodskap se gerigtheid op die hedendaagse konteks nagevors en beskryf word, word hermeneuse genoem (Coetzee, 1997:2-5). Hermeneuse is dus die eksegetiese proses waardeur die Skrifboodskap geaktualiseer word.

Die uitgangspunt by hermeneuse is dat dit steeds die Woord van God moet wees wat in die konteks van die hedendaagse mens spreek. Hermeneuse is daarop gemik dat God, en God alleen, aan die woord moet wees. Hermeneuse kan daarom nie verstaan en toegepas word los van deeglike voorafgaande eksegese van die Skrif nie. Hermeneuse is immers die toepassing van die boodskap van die teks soos dit in die proses van eksegese verklaar is. Daarom is explicatio en applicatio begrippe wat sentraal in die gereformeerde eksegese en hermeneuse staan.

Die gereformeerde benadering tot Skrif-eksegese het dus 'n bepaalde Skrifbeskouing ten grondslag wat kernagtig soos volg uiteengesit kan word: 
- Die Bybel is die Woord van God en nie bloot woorde oor God nie.

- Die Bybel is die openbaring van God aan die mens en nie menslike denke oor die openbaring van God nie.

- Die Bybel is ten volle Woord van God en nie slegs 'n boek waarin die Woord van God op plekke voorkom nie.

- Die Bybel is Woord van God, omdat dit God se Woord is - nie in soverre dit Woord van God is nie.

- Die Woord van God is tydgerig en nie tydsgebonde of tydloos nie.

God se Woord kom tot mense deur mense. In die NuweTestamentiese vakgebied word uitgegaan van die standpunt dat elke skrywer van die boeke van die Nuwe Testament 'n baie duidelike intensie of bedoeling gehad het by die skryf van die boek of brief. Hierdie hermeneutiese beginsel word alreeds by Calvyn aangetref (Floor, 1980:18; Jordaan, 1991:19, 20-21) en duideliker kan so 'n outeurs-intensie seker nie gevind word nie as by die skrywers van die briewe in die Nuwe Testament. Tog impliseer die boeke van die Nuwe (en Ou) Testament nie menslike nadenke oor die openbaring van God nie. Die Gees van God as auctor primarius het met daardie selfde boeke 'n goddelike intensie gehad, naamlik die openbaring van God. Hierdie goddelike openbaring word genoem die Woord van God - 'n waarheid wat objektief buite die mens om gegee is.

Hierdie beginsel is van kardinale belang by die verstaan van die argument in hierdie artikel. Die openbaring van God, wat objektief buite die mens om gegee is, moet dus sover menslik moontlik, verklaar word in die eksegetiese proses. Die intensie van die menslike skrywer, sowel as die Heilige Gees, het tot gevolg dat betekenis (waarheid) in die Woord van God is, wat verklaar en toegepas moet word. Daar kan (en mag) dus nie sprake wees van die toekenning van 'n eie interpretasie of eie opinie (of eie bedoeling) aangaande die intensie van die Heilige Gees soos wat Hy die Bybel deur mense op Skrif laat neerpen het nie. Hierdie laaste opmerking het betrekking op die hele proses van eksegese, wat verklaring en toepassing insluit.

Ten opsigte van die toepassing van die Skrifboodskap (applicatio) is die hermeneutiese sleutel in gereformeerde eksegese die tydgerigtheid van die Woord van God. 'n Tydgebonde Woord sou impliseer dat God se Woord eenmalig gekom het binne spesifieke omstandighede en slegs bedoel was vir daardie spesifieke omstandighede, sonder dat dit verderaan enige betekenis sou inhou vir 
lesers van latere tye. 'n Tydlose Woord van God sal weer impliseer dat elke woord in die Bybel net so van toepassing sou wees vir alle kontekste van alle tye. Maar omdat die Skrif tydgerig is moet die (tydgerigte) woorde van die Bybel oor-"vertaal" word - dit wil sê aan 'n proses van hermeneuse ( $\dot{\epsilon} \rho \mu \eta v \in \epsilon^{\prime} \alpha$ ) onderwerp word - ten einde die toepaslikheid daarvan vir die eietydse konteks te verstaan (let wel: verstaan en nie skep nie).

Binne die reeds bespreekte raamwerk van Skrifbeskouing wil die gereformeerde Skrifverklaring dus voortdurend wys op die belangrikheid van die hermeneuse waarbinne die tydgerigte Woord van God gekonkretiseer word. Hierbinne neem geloof in die Bybel as tydgerigte Woord van God 'n sentrale plek in (vgl. Groothuis, 2000:7; Van Wyk, 1995:242). Omdat dit God is wat Homself in sy Woord openbaar, gaan dit dus ook om geloof in die God van die Woord van God (Van Wyk, 1995:242) soos Hy Hom in sy Woord openbaar. Die basis vir die gesag van die Bybel is immers juis daarin te vind dat God Self die Een is wat deur en vanuit die Skrif tot ons spreek (Floor, 1980:15). Hoe kan die mens homself dan so hoog ag dat hy 'n ander betekenis wil toeken aan die Woord van God?

Geloof in die Bybel as gesagvolle Woord van God is derhalwe 'n voorveronderstelling waarmee die gereformeerde Skrifverklaarder die Bybel benader. Dit rig alle eksegetiese arbeid - gevolglik ook die hermeneuseproses. Gereformeerde hermeneuse glo dat God se Woord ook op vandag van toepassing is. Die proses van hermeneuse wat gegrond is op die Skrifbeskouing van en geloof in die Bybel as gesagvolle Woord van God, wil dus die betekenis van die Skrifboodskap toepas op die hedendaagse konteks. God wat eenmaal 'n tydgerigte woord gespreek het, spreek daardeur ook tydgerig tot die konteks van vandag.

\section{8. 'n Beoordeling van betekenisskeppende kontekstualisering vanuit 'n visie vir gereformeerde hermeneuse}

Hoe vergelyk 'n kontekstualisering met postmodernistiese uitgangspunte of voorveronderstellings met die visie van gereformeerde hermeneuse? Om op hierdie vraag te antwoord sou die postmodernistiese en gereformeerde uitgangspunte ten opsigte van Skrifbeskouing en die gebruik van voorveronderstellings teen mekaar opgeweeg kan word. Met die oog op die doel van hierdie artikel is dit egter belangriker om vanuit ' $n$ visie vir gereformeerde 
hermeneuse betekenisskeppende kontekstualisering binne 'n postmodernistiese denkklimaat te beoordeel.

Ten eerste is dit nodig om aan te toon wat met "n visie vir gereformeerde hermeneuse" bedoel word. Met opset word gekies om nie van gereformeerde hermeneuse as sodanig te praat nie, maar van 'n visie vir gereformeerde hermeneuse. Die woord "visie" impliseer 'n vooruitsig op iets waarna gestreef word - iets wat bereik wil word. Daarom dui "'n visie vir gereformeerde hermeneuse" daarop dat die hermeneuse soos dit binne die gereformeerde hermeneutiek beskryf en in die gereformeerde eksegese beoefen word, nie 'n afgehandelde saak is nie. Die gereformeerde hermeneuse word nie as "volmaak" voorgehou nie, maar as 'n proses wat steeds aan verbetering en hersiening onderworpe is - 'n ideaal wat nagestreef word.

'n Visie vir gereformeerde hermeneuse hou ook verband met die tydgerigte aard van die Woord van God. Soos reeds gestel is, is God se Woord geldend vir die konteks van die tyd, of dit nou 2000 jaar gelede was, of dit vandag is en of dit 2000 jaar van nou af is. Tye verander en daarmee saam ook die konteks. Daarom poog die gereformeerde hermeneuse voortdurend om die toepaslikheid van God se Woord te verstaan en te beskryf vir mense in hulle spesifieke konteks en omstandighede. Die vertrekpunt bly egter altyd die Woord van God. Hermeneuse wil altyd die Woord van God oorbring vanaf die "toe daar" tot die "nou hier".

Deist (1994b:260-262) prys die hermeneutiese uitgangspunte wat W.S. Vorster aangedui het aan as die rigting waarin teologiebeoefening in die hedendaagse konteks van Suid-Afrika moet beweeg. Onder meer word daarop gewys dat Vorster sy navorsing telkens binne die denkraamwerk van die postmodernisme uitgevoer het. Deist (1994b:259) gee self toe dat 'n postmodernistiese werkswyse soos dié van Vorster uit die oogpunt van die fundamentalisme afgemaak kan word as "relativisties". Hiervolgens is ook die gereformeerde teologie in sy afwysing van die postmodernistiese denkwyse eg "fundamentalisties". Deist se tipering van die fundamentalisme is egter ontoereikend. Jordaan (1991:5-8) toon aan dat die gereformeerde teologie duidelik van die fundamentalisme onderskei moet word en eerder as gereformeerdfundamenteel getipeer moet word.

Die gevaar van die invloed van die postmodernisme is grootliks geleë in die relativistiese aard daarvan. Die relativistiese benadering tot die Bybel erken ook, soos die gereformeerde benadering, dat die 
Bybel 'n boodskap vir vandag het, maar 'n boodskap wat relatief staan tot die mens se ervaring daarvan. Jordaan (1991:9) skryf dat die relativisme via Bultmann en Barth gegroei het tot by die relasionele waarheidsbeskouing van Kuitert in die sewentiger- en tagtigerjare van die vorige eeu. Die relasionele waarheidsidee ontken enige objektiewe waarheid. Dit erken slegs ' $n$ waarheid wat altyd binne 'n relasie tot die mens te voorskyn tree. Die mens en sy omstandighede is medebepalend vir die Skrifboodskap en die waarheid daarvan.

Die ontkenning van 'n objektiewe waarheid in die Bybel het ernstige konsekwensies. Die bestaan van 'n objektiewe waarheid, wat die openbaring van God is, dui nie op die ontginning van hierdie waarheid op 'n positiwistiese wyse nie. Eerder sou 'n mens kon sê dat die objektiewe waarheid wat in die Bybel tot die mens kom, die menslike subjek rig in sy eksegetiese arbeid en sy verstaan van die teks, om sodoende die betekenis van die teks vir die konteks te konkretiseer. Geloof in die objektiewe, gesagvolle waarheid van die Skrif as tydgerigte Woord van God vorm en omvorm eerder die subjektiewe mens, as wat die mens veronderstel is om op 'n subjektiewe wyse die Woord van God te probeer vorm en omvorm ten einde betekenis te skep. Hermeneuse (of kontekstualisering, vir die doeleindes van hierdie argument) gee nie aan die verklaarder vrymag om enige betekenis aan die teks toe te ken nie.

Geen mens is egter konteksloos nie. Moontlik mag dit een van die positiewe aspekte wees wat die postmodernisme uitlig en beklemtoon. In plaas van 'n oorbeklemtoning van die konteks van vandag, kan die Skrif egter veel eerder 'n vars blik gee op die konteks waarin die hedendaagse mens leef, woon en werk. Ook geen teologie word konteksloos beoefen nie. Elke Skrifverklaarder bevind homself op 'n spesifieke oomblik in die tyd midde in 'n bepaalde kulturele, politieke of maatskaplike konteks. Tog mag dit nooit die bril word waardeur daar na die Skrif gekyk word nie. Die voorkoms en bestaan van sulke subjektiwistiese kontekstualisering binne die huidige denkklimaat, is nie genoegsame rede waarom dit klakkeloos gevolg moet word nie. Veel eerder moet dit 'n genoegsame rede tot prinsipiële verantwoording wees.

Die klem wat tans geplaas word op die rol van die leser (Wright, 2000:48-49) laat by hedendaagse navorsers en teoloë die vraag ontstaan of daar nie gesoek moet word na 'n nuwe hermeneutiek nie - 'n nuwe sleutel, omdat die ou sleutel skynbaar nie meer die vrae en probleme van vandag kan hanteer nie. Die probleem word vererger wanneer meer kritiese teoloë met meer kritiese metodes 
antwoorde bereik waarby die gereformeerde eksegese en hermeneuse skynbaar nie kan uitkom nie (vgl. Draper, 1991:238). Spanning ontstaan wanneer nuwe resultate met sogenaamde "ou" metodes verkry wil word.

Die impak van die postmodernistiese denke op die hedendaagse kontekstualisering van die Skrif plaas 'n appèl op die gereformeerde hermeneutiek om hom prinsipieel te verantwoord oor sy metodes van Skrifverklaring en Skriftoepassing. Daarom sal gereformeerde kenteoretiese wetenskapsbeoefening duidelik en ondubbelsinnig sy voorveronderstellings moet verklaar. Dit moet veral duidelik stel dat wetenskapsbeoefening binne die gereformeerde kader daarvan uitgaan dat die werklikheid van God se openbaring, soos dit in die Skrif tot die mens kom, en geloof in die God van die Woord van God, die raamwerk bied van kennis (en geloof). Rasionele wetenskapsbeoefening in die teologie berus op die slagspreuk: Ons weet, daarom glo ons (kennis gegrond op wetenskaplike resultate). Die gereformeerde wetenskap word egter begrond deur die belydenis: Ons glo, daarom weet ons (vgl. Heb. 11:3).

\section{Gevolgtrekking}

Die finale woord oor gereformeerde hermeneuse is sekerlik nie gespreek nie. In die hermeneuseproses word deeglik daarmee rekening gehou dat kontekste verander. In die hermeneuseproses word ook erken dat die mens nie in staat is om die objektiewe waarheid van God waarna die mens in sy sondige, subjektiewe bestaan streef, in 'n enkele moment te kan saamvat nie. Gereformeerde hermeneuse berus wel op die besef en die besliste belydenis: God se Woord bied 'n tyd vir elke dag, of hierdie dag nou premodernisties, modernisties, of postmodernisties is.

Hermeneuse het wel 'n temporele karakter, want elke dag is nuut, elke eeu is nuut. Daarom sal 'n visie vir gereformeerde hermeneuse met die oog op die kontekstualisering van die verklaarde Woord, God se Woord telkens van nuuts af tot die konteks moet bring. Die gereformeerde ideaal is nie ons eie en eietydse woorde oor God nie. Inteendeel, die blywende gereformeerde ideaal en visie is ' $\mathrm{n}$ omhelsing van God se Woord in ons tyd.

\section{Geraadpleegde bronne}

ADAM, A.K.M. 1995. What is postmodern biblical criticism? (In Via, D.O., ed. Guides to Biblical scholarship. Minneapolis: Fortress. p. 1-81.) 
BERKHOF, H. \& DE JONG, O.J. 1967. Geschiedenis der Kerk. Nijkerk: Callenbach.

BARTH, K. 1968. The epistle to the Romans. Translated from the 6 th edition by E.C. Hoskyns. London: Oxford University Press.

BLANK, G.K. 1986. Deconstruction: Entering the Bible through Babel. Neotestamentica, 20:61-67.

BOTHA, J. 1988. Semeion. Pretoria: NG Kerkboekhandel.

CHOPP, R.S. 1997. Feminist and womanist theologies. (In Ford, D.F., ed. The modern theologians. An introduction to Christian theology in the twentieth century. Massachusetts: Blackwell. p. 389-404.)

COETZEE, J.C. 1997. Hermeneutics and exegesis of the New Testament. Potchefstroom: EFJS Drukkers.

D'ASSONVILLE, V.E. 1976. Die dwaasheid om te preek. Johannesburg: Boekhandel De Jong.

DALFERTH, I.U. 2000. "I determine what God is!" Theology in the age of "Cafeteria Religion". Theology Today, 57(1):5-23.

DE JONG, Tj. 1993. De theoloog en Hét Boek. Standvastig: 9-12, Maart.

DE VILLIERS, P.G.R. 1991. The end of hermeneutics? On New Testament studies and postmodernism. Neotestamentica, 25(1):145-156.

DE WIT, J.H. 1995. De afdaling van het nieuwe Jeruzalem: Bevrijding en hermeneutiek. Gereformeerd Theologisch Tijdschrift, 95(4):181-193.

DEIST, F.E. 1994a. Onlangse konsepte in teksuitleg en hulle konsekwensies vir die (gereformeerde) teologie. In die Skriflig, 28(2):165-178.

DEIST, F.E. 1994b. Post-modernism and the use of Scripture in theological argument: Footnotes to the apartheid theological debate. Neotestamentica, 28(3):253-263.

DRAPER, J.A. 1991. 'For the Kingdom is inside of you and it is outside of you': contextual exegesis in South Africa. (In Hartin, P.J. \& Petzer, J.H., eds. Text and interpretation. Leiden: Brill. p. 235-257.)

DUVENAGE, B. 1999. Hoe kan die kerk die postmoderne mens bereik? Die Kerkblad: 26-28, Maart 24.

ENGLAND, F. 2004. Mapping postcolonial biblical criticism in South Africa. Neotestamentica, 38(1):88-99.

FLOOR, L. 1979. Hoe gebruik die teoloog die Skrif? Koers, 44(1):8-17.

FLOOR, L. 1980. Die hermeneutiek van Calvyn. In die Skriflig, 14(55):13-20.

GAYBBA, B. 1998. Theology: the first 19 centuries. (In Maimela, S. \& König, A., eds. Initiation into theology. The rich variety of theology and hermeneutics. Pretoria: Van Schaik. p. 27-48.)

GREIJDANUS, S. 1946. Schriftbeginselen ter Schriftverklaring. Kampen: Kok.

GROOTHUIS, D. 2000. The postmodern challenge to theology. Themelios, 25(1):4-22.

HARTIN, P.J. 1991. Disseminating the Word: A deconstructive reading of Mark 4:1-9 and Mark 4:13-20. (In Hartin, P.J. \& Petzer, J.H., eds. Text and interpretation. Leiden: Brill. p. 187-200.)

HERHOLDT, M.D. 1998a. Postmodern theology. (In Maimela, S. \& König, A., eds. Initiation into theology. The rich variety of theology and hermeneutics. Pretoria: Van Schaik. p. 215-229.)

HERHOLDT, M.D. 1998b. Postmodern hermeneutics. (In Maimela, S., \& König, A., eds. Initiation into theology. The rich variety of theology and hermeneutics. Pretoria: Van Schaik. p. 451-470.) 
HENDRIKS, H.J. 1996. Modernisme: ten diepste ons identiteit? In die Skriflig, (30)4:489-501.

HUNTER, J.H. 1987. Deconstruction and Biblical texts: Introduction and critique. Neotestamentica, 21(2):125-140.

JORDAAN, G.J.C. 1991. Skrifbeskouing: Deurslaggewende faktor by Skrifverklaring. Inougurele rede. Potchefstroom.

JORDAAN, G.J.C. 1994. Postmodernistiese hermeneutiek - 'n doodloopstraat. Ongepubliseerde diktaat. Potchefstroom.

JORDAAN, G.J.C. 1999. Postmodernistiese Skrifuitleg - 'n doodloopstraat. Die Kerkblad: 10-12, Maart 24.

KRUGER, G.J. 1991. Die wit teologie. Ongepubliseerde Th.B.-werkstuk. Teologiese Skool Potchefstroom.

KUHN, T.S. 1970. The structure of scientific revolutions. Chicago: University of Chicago Press.

KUHN, T.S. 1975. The structure of scientific revolutions. Chicago: University of Chicago Press.

LATEGAN, B.C. 1984. Current issues in the hermeneutical debate. Neotestamentica, 18:1-15.

LOADES, A. 1997. Feminist theology. (In Ford, D.F., ed. The modern theologians. An introduction to Christian theology in the twentieth century. Massachusetts: Blackwell. p. 575-584.)

MAIMELA, S. 1998. Black theology. (In Maimela, S. \& König, A., eds. Initiation into theology. The rich variety of theology and hermeneutics. Pretoria: Van Schaik. p. 111-119.)

MBITI, J.S. 1998. African theology. (In Maimela, S. \& König, A., eds. Initiation into theology. The rich variety of theology and hermeneutics. Pretoria: Van Schaik. p. 141-157.)

NEVEN, G.N. 1993. Een eigen theologischen ervaringsweg. Centraal Weekblad: 5, Jan. 15.

PORTER, S.E. \& CLARKE, K.D. 1997. What is exegesis? An analysis of various definitions. (In Porter, S.E., ed. Handbook to exegesis of the New Testament. New York: Brill. p. 3-21.)

ROSSOUW, G.J. 1993. Theology in a postmodern culture. Hervormde Teologiese Studies, 49(4):894-907.

ROSSOUW, H.W. 1981. Wetenskap, interpretasie, wysheid. Port Elizabeth: UPE.

SCHULZE, L.F. 1981. Teologie in stroomversnelling. Potchefstroom: Potchefstroomse Teologiese Publikasies.

SILVA, M. 1994. Contemporary approaches to Biblical interpretation. (In Kaiser, W.C. \& Silva, M., eds. An introduction to Biblical hermeneutics. The search for meaning. Grand Rapids: Zondervan. p. 229-248.)

SNYMAN, G. 1992a. Kenteoretiese besinning oor teologiebeoefening aan die Teologiese Skool van Potchefstroom die afgelope twintig jaar. In die Skriflig, 26(2):247-266.

SNYMAN, G. 1992b. Binnegevegte in die GKSA: verskuiwing van 'plausibility structures'? In die Skriflig, 26(3):351-367.

SPANGENBERG, I.J.J. 1994. Paradigmaveranderinge in die Bybelwetenskappe. 'n Bydrae tot die gesprek tussen die Bybelwetenskappe en Sistematiese Teologie. Religie en Teologie, 1(2):144-184. 
STANTON, G.N. 1977. Presuppositions in New Testament criticism. (In Marshall, I.H., ed. New Testament interpretation. Exeter: Paternoster. p. 60-71.)

TRACY, D. 1994. Theology and the many faces of postmodernity. Theology Today, 51(1):104-114.

UKPONG, J. 2001. New Testament hermeneutics in Africa: Current challenges and future possibilities. Neotestamentica, 35(1-2):147-167.

VAN AARDE, A.G. 1988. Historical criticism and holism: heading towards a new paradigm? (In Mouton, J., Van Aarde, A.G., Vorster, W.S., eds. Paradigms and progress in theology. Pretoria: Human Sciences Research council. p. 49-64.)

VAN DEVENTER, H.J.M. 1996. 'n Paradigma vir Gereformeerde teologiese wetenskapsbeoefening - 'n voorstel. Koers, 61(4):441-456.

VAN DEVENTER, H.J.M. 1998. Oor paaie, sirkels en waarhede: 'n Bydrae met betrekking tot die huidige hermeneutiese gesprek. Acta Theologica, 18(1):77-95.

VAN DEVENTER, H.J.M. 1999. 'n Verband tussen ontwikkelinge binne filosofiese hermeneutiek en ontwikkelinge in benaderings tot Bybelinterpretasie. Koers, (64)4:393-413.

VAN IERSEL, B.M.F. 1982. De existentiale interpretatie. (In Klijn, A.F.J., red. Inleiding tot de studie van het Nieuwe Testament. Kampen: Kok. p. 112126.)

VAN WYK, J.H. 1995. Die relevansie van die Gereformeerde teologie vir vandag. In die Skriflig, 29(1-2):241-267.

VELDSMAN, D.P. 1994. When reality has become a pale reflection of our images ... Imagining faith in Christ in a postmodern context. Skrif en Kerk, 15(1):120-134.

VERGEER, W.C. 1993. Die kontekstualiseringstrategie in Kolossense 2:17. Potchefstroom: PU vir CHO. (Th.M.-verhandeling.)

VERGEER, W. 1999. Die postmodernisme - 'n gevaarlike reus? Die Kerkblad: 12-14, Maart 24.

VOGEL, G.M. 1989. Kontekstualisering van die evangelie: 'n kritiese literatuurstudie oor die gebruik van die begrip vanuit missiologiese perspektief. Potchefstroom: PU vir CHO. (Th.M.-werkstuk.)

VORSTER, J.M. 1977. Die kerk in die moderne wêreld - 'n diagnose. In die Skriflig, 11(41):14-29.

VORSTER, J.M. 1994. Die kerk in 'n nuwe konteks. In die Skriflig, 28(3):309327.

VORSTER, J.M. 1996. Is die kerk funksioneel? Gedagtes oor gereformeerde kerkvernuwing in 'n postmoderne konteks. Potchefstroom: Potchefstroomse Teologiese Publikasies.

VORSTER, J.M. 1998. Periodisation in church history. Studia Historiae Ecclesiasticae, 24(1):208-225.

VORSTER, J.M. 1999a. Die ontwikkeling van postmoderniteit. Die Kerkblad: 1012, Maart 24.

VORSTER, J.M. 1999b. 'n Waarskynlike bedieningsmilieu vir die GKSA in die dekades na 2000. In die Skriflig, 22(1):99-119.

WARD, G. 1997. Postmodern theology. (In Ford, D.F., ed. The modern theologians. An introduction to Christian theology in the twentieth century. Massachusetts: Blackwell. p. 585-601.) 
WENDLAND, E.R. 1999. Contextualising the potentates, principalities and powers in the Epistle to the Ephesians. Neotestamentica, 33(1):199-223.

WITHERS, J.R., ed. 1994. Conceptual dictionary. Durban: Juta.

WRIGHT, C.J.H. 2000. Interpreting the Bible among the world religions. Themelios, 25(3):35-54.

Kernbegrippe:

gereformeerde hermeneuse; 'n visie vir kontekstualisering van die Nuwe Testament postmodernistiese paradigma

Key concepts:

contextualisation of the New Testament postmodernist paradigm

reformed hermeneusis; a vision for 
